\title{
DERIVATIVES AND THE WEALTH OF NATIONS
}

Derivatives are financial weapons of mass destruction.

Warren Buffet

At a time when the world economy is engulfed into the mother of all financial crises, it is indeed tempting and opportune to find derivatives guilty as charged for creating financial chaos. This book is not an indictment of financial derivatives to be feared as "financial weapons of mass destruction" nor is it a call for multilateral disarmament or signing a nonproliferation treaty! Derivatives may be feared but they cannot be avoided nor ignored (abstinence is not an option) as they permeate many of the key goods and services which are at the core of modern life: for example, the price of energy is largely influenced by oil and natural gas derivatives and the cost of securitized consumer finance (variable rate home mortgages and automobile loans) embodies interest rate derivatives and credit default swaps.

Instead this book recounts the financial debacles which - triggered by the misuse of derivatives - devastated both financial and nonfinancial firms. By presenting a factual analysis of how the malpractice of derivatives played havoc with derivative end-user and dealer institutions, a case is made for vigilance not only to market and counterparty risk, but also operational risk in their use for risk management and proprietary trading. Clear and recurring lessons across the different stories should be of immediate interest to financial managers, bankers, traders, auditors, and regulators who are directly or indirectly exposed to financial derivatives. The second purpose of this book is more modest: by telling real-life "horror" stories it purports to debunk the mystifying pseudocomplexity of derivatives and to take the uninitiated reader on 
a "grand tour" of financial engineering and derivatives. Indeed the reader is introduced step by step to real-life companies and the vicissitudes that they experienced in misusing the arcane derivatives.

\section{WHAT ARE DERIVATIVES?}

Derivatives are financial contracts, whose value is "derived" from the future price of an underlying asset such as currencies, commodities, interest rates, and stock price indices. Even though each chapter will introduce one specific derivative in much detail, it is helpful at this early stage to provide definitions for the four major families of derivatives, whose architecture is identical across different classes of underlying assets:

- Forwards are legally-binding contracts calling for the future delivery of an asset in an amount, at a price and at a date agreed upon today. For example, a 90-day forward purchase of 25 million pound sterling ( $\mathfrak{f})$ at the forward rate of $\$ 1.47=£ 1$ signed on April 13, 2015 happens in two steps: today, April 13, 2015 a contract is signed spelling out the nature of the transaction (forward purchase of the pound sterling), the amount ( $£ 25$ million), the price ( $\$ 1.47)$, the time of delivery (90 days hence or July $17,2015)$ but nothing happens physically beyond the exchange of legal promises. Ninety days later, the contract is executed by delivering $£ 25 \times 1.47=\$ 36.75$ million and taking delivery of $£ 25$ million. The contract is carried out at the forward rate regardless of the spot price (that is the price prevailing on delivery day) of the pound sterling. Forwards are tailor-made contracts also known as over-the-counter and - as such - expose the signatories to counterparty risk - that is the risk that the other party may default on its delivery obligations. Forwards are available on commodities such as copper or oil and other assets. Forwards will be the "financial weapon of mass destruction" in the first three chapters involving respectively a major Japanese oil company Showa Shell, Citibank, and Bank Negara — the Central Bank of Malaysia.

- Futures are close cousins of forward contracts with some material differences. Futures are standardized contracts, whose amount and delivery date are set by an organized exchange: for example, sterling futures can only be delivered in March, June, September, and December (third Wednesday of calendar month) and are available in multiples of £62,500). The lack of flexibility in designing a tailor-made contract (as in the case of forwards) is compensated by the liquidity of the contract, which can be closed at any time before expiry. Because futures are entered with well-capitalized exchanges such as the Chicago Board of Trade or the New York Mercantile Exchange, there is no counterparty risk to be concerned with as the exchange will require any contract holder to post a margin - a form of collateral - 
which ensures that the contract holder is able to fulfill the terms of the contract at all times regardless of the spot price. Futures will be the "financial weapon of mass destruction" in Chapters 5, 6, and 7 featuring respectively the hedge fund Amaranth Advisors LLC, the German metal-processing and engineering firm Metallgesellschaft and the Japanese trading company Sumitomo.

- Options are securities which give you the right to buy (call option) or sell (put option) an asset (currency, commodity, stocks, bonds) for an extended period (American option) or at a particular future point in time (European option) at an agreed price today (strike price) for an upfront cash-flow cost (premium). In one of the largest options ever contracted, U.K. company Enterprise Oil Ltd. paid more than \$26 million for a 90-day currency option to protect against exchange rate fluctuations on $\$ 1.03$ billion of the $\$ 1.45$ billion that it had agreed to pay for the oil exploration and production assets of U.S.-based transportation company Texas Eastern Inc. The option - a dollar call option - gave Enterprise the right to buy dollars at a dollar/sterling rate of $\$ 1.70$. The dollar/sterling exchange rate was $\$ 1.73$ when Enterprise Oil bought the option on March 1: "We are bearish on sterling," says group treasurer Justin Welby. "And we did a very careful calculation between the price of the option premium (which is cheaper the further out-of-the-money) and how much we could afford the dollar to strengthen. We decided that this was the best mix between the amount of protection we could forgo and the amount of upfront cash we were prepared to pay out for the option. ${ }^{1}$ "Ninety days later, the pound stood at $\$ 1.7505$, which made the call option just about redundant at the modest cost of \$26 million for Enterprise Oil Ltd. Options are available not only on currencies, but also on stock price indices, interest rates, and commodities. They are the "financial weapon of mass destruction" in Chapters 8, 9, 10, and 11 featuring respectively Allied Lyons, Barings Bank, Allied Irish Banks, and Société Générale.

- Swaps are contracts between two parties agreeing to exchange (swap) cash-flows over a determined period. The most common swaps are interest rate swaps - where one party pays a fixed interest rate based on a notional amount and the counterparty pays a floating rate keyed to the same notional amount. Cross-currency and commodity swaps are also common. Mexicana de Cobre - a Mexican coppermining company — decided to hedge against volatile copper prices on the London Metal Exchange ${ }^{2}$ to secure medium-term financing at significantly more favorable terms than it was currently paying. It entered into a copper price swap with Metallgesellschaft (one of the leading metal-processing firms) whereby for a period of 3 years it committed to deliver monthly 4,000 metric tons of copper at a guaranteed

1 “Enterprise Oil \$25 million call option”, Corporate Finance (April 1989).

2 This innovative deal was engineered by Dr Gaylen Byker, See Jacque, L. L. and G. Hawawini. Myths and realities of the global market for capital: Lessons for financial managers, Journal of Applied Corporate Finance (Fall 1993). 
price of $\$ 2,000$ per metric ton regardless of the spot price on the world market. In effect the swap was tantamount to a portfolio of 36 forward contracts with maturities ranging from 1 to 36 months at a forward rate of \$2,000 per metric ton. Most swaps are over-the-counter rather than exchange-traded. They are the "financial weapons of mass destruction" in Chapters 12, 13, 14, 15, 16 and 17 featuring respectively Procter \& Gamble, Gibson Greeting Cards, Orange County, Long-Term Capital Management and last but not least AIG and JP Morgan Chase.

\section{A BRIEF HISTORY OF DERIVATIVES}

From immemorial times, traders have been faced with three problems: how to finance the physical transportation of merchandise from point A to point B - perhaps several hundreds or thousands of miles apart and weeks or months away - how to insure the cargo (risk of being lost at sea or to pirates) and last, how to protect against price fluctuations in the value of the cargo across space (from point A to point B) and over time (between shipping and delivery time). In many ways, the history of derivatives contracts parallels the increasingly innovative remedies that traders devised in coping with their predicament.

Ancient Times. Trade carried over great distance is probably as old as mankind and has long been a source of economic power for the nations which embraced it. Indeed international trade seems to have been at the vanguard of human progress and civilization: Phoenicians, Greeks, and Romans were all great traders, whose activities were facilitated by marketplaces and money changers which set fixed places and fixed times for exchanging goods. Some historians even claim that some form of contracting with future delivery appeared as early as several centuries BC. At about the same time in Babylonia - the cradle of civilization - commerce was primarily effected by means of caravans. Traders bought goods to be delivered in some distant location and sought financing. A risk-sharing agreement was designed whereby merchantsfinanciers provided a loan to traders, whose repayment was contingent upon safe delivery of the goods. The trader borrowed at a higher cost than ordinary loans would cost to account for the purchase of an "option to default" on the loan contingent upon loss of cargo. As lenders were offering similar options to many traders and thereby pooling their risks they were able to keep its cost affordable. ${ }^{3}$

Middle Ages. Other forms of early derivatives contracts can be traced to medieval European commerce. After the long decline in commerce following the demise of the Roman Empire, Medieval Europe experienced an economic revival in the twelfth

\footnotetext{
${ }^{3}$ Jorion, P. Big Bets Gone Bad (Academic Press, 1995), p. 138.
} 
century around two major trading hubs: in Northern Italy, the city-states of Venice and Genoa controlled the trade of silk, spices, and rare metals with the Orient; in Northern Europe, the Flanders (Holland and Belgium) had long been known for their fine cloth, lumber, salt fish, and metalware. It was only natural that trade would flourish between these two complementary economic regions and somehow, as early as the 1100s, Reims and Troyes in Champagne (Eastern France) held trade fairs, which facilitated their mercantile activity: there, traders would find money changers, storage facilities, and most importantly protection provided by the Counts of Champagne. Soon rules of commercial engagement started to emerge as disputes between traders hailing from as far-away as Scandinavia or Russia had to be settled: a code of commercial law known as "law merchant" - enforceable by the "courts of the fair" was progressively developed. Although most transactions were completed on a spot basis "an innovation of the medieval fairs was the use of a document called the "lettre de faire" as a forward contract which specified the delivery of goods at a later date."

In 1298, a Genoese merchant by the name of Benedetto Zaccharia was selling 30 tons of alum ${ }^{5}$ for delivery from Aigues Mortes (Provence) to Bruges (Flanders). ${ }^{6}$ Maritime voyage around Spain and the Atlantic coast of France was then hazardous and fraught with dangers: the cargo could be lost at sea or to pirates. Zaccharia found two compatriot financiers Enrico Zuppa and Baliano Grilli, who would assume the risk. Here is how it worked: Zaccharia sold "spot" the alum to Zuppa and Grilli and entered into a forward repurchase contract contingent upon physical delivery. The repurchase price was significantly higher than the spot price in Aigues Mortes. It reflected the cost of physical carry from Aigues Mortes to Bruges (several months at sea), insurance against loss of cargo and the option to default granted to Zaccharia in the case of nondelivery. The merchant Zaccharia had secured financing and insurance in the form of a forward contingent contract.

Renaissance. If medieval fairs had gone a long way in establishing the standards for specifying the grading and inspection process of commodities being traded as well as date and location for delivery of goods, it fell short of the modern concept of futures traded on centralized exchanges. The first organized futures exchange was the Dojima rice market in Osaka (Japan), which flourished from the early 1700s to World War II. It grew out of the need of feudal landlords whose income was primarily based on unsteady rice crops to cope with a growing money economy. By shipping

\footnotetext{
${ }^{4}$ Teweles, R. J. and F. J. Jones, edited by Ben Warwick, The Futures Game: Who Wins, Who Loses and Why (McGraw Hill, 1999, 3rd edn.), p. 8.

${ }^{5}$ White mineral salt.

${ }^{6}$ Favier, J. Les Grandes Découvertes (Le Livre de Poche, 1991), cited in Bryis and de Varenne (2000).
}

${ }^{7}$ Spot sale is for immediate delivery and cash payment. 
surplus rice to Osaka and Edo, landlords were able to raise cash by selling warehouse receipts of their rice inventory in exchange for other goods on sale in other cities. Merchants who purchased these warehouse receipts soon found themselves lending to cash-short landlords against future rice crops. In 1730, an edict by Yoshimune - also known as the "rice Shogun" - established futures trading in rice at the Dojima market apparently in an effort to stem the secular decline in rice prices. It certainly allowed rice farmers to hedge against price fluctuations between harvests. Interestingly, all the hallmarks of modern standardized futures contract were found in the Dojima rice futures market ${ }^{8}$ : each contract was set at $100 k o k u^{9}$ and contract durations were set according to trimester trading calendars consisting of a spring semester (January 8April 28), summer term (May 7-October 9), and a winter term (October 17-December 24). All trades were entered in the "book" transaction system, where the names of the contracting parties, amount of rice exchanged, futures price, and terms of delivery were recorded. Transactions were cash-settled (delivery of physical rice was not necessary) at the close of the trading term. Money changers soon functioned as clearinghouses de facto eliminating the counterparty risk by forcing margin requirements on individual rice traders, which were marked-to-market every 10 days. ${ }^{10}$

Industrial Revolution. Forward contracts progressively evolved from the need to hedge price risk associated with international trade: consider the case of a mining firm in California shipping copper to London and wanting to lock in the value of its merchandise by selling "forward" (known then as on "a to arrive basis") its cargo possibly at a lower price that it would expect to receive several months later. A copper processing firm in London may want to lock in the value of its core raw material input so that, in turn, it could bid on construction projects at firm prices. Neither firm would know of each other being domiciled far apart. A middle man would act as a match-maker: merchant banks (or their ancestors) having representation in the two distinct physical locations would be able to arrange the trade: They would receive a handsome fee for bringing the two parties together and acting as a guarantor of the good execution of the transaction.

In the early 1800 s, grain commerce in the United States was vulnerable to large swings in prices: upon harvesting farmers would flood the market with their crop and grain prices would collapse. Within a few months shortages would develop and prices would rebound. Instead of shipping their crop all at once and face up to inadequate

\footnotetext{
${ }^{8}$ West, M. D. Private ordering at the world's first future exchange, Michigan Law Review (August 2000).

${ }^{9} \mathrm{Koku}$ is a unit of measurement used in medieval Japan and which corresponds to the amount of rice consumed by a Japanese in one year. It is equal to 180 Litres.

${ }^{10}$ Op. Cit. p. 2588.
} 
storage facilities, farmers (sellers) and millers (buyers) increasingly turned to forward contracting as a way to cope with price volatility while staggering over time grain delivery: Chicago was rapidly emerging as a hub for grain storing, trading, and subsequent distribution eastwards along rail lines or through the great lakes. In 1848, organized futures trading made its debut with the Chicago Board of Trade: forward contracts were morphed into futures through standardization of contracts which allowed easier (uniform grading of commodities) and safer trading (margin requirement eliminates counterparty risk). Physical commodities both hard (minerals) and soft (agricultural) became the object of futures trading.

Information Age. More than a century later, the burst of innovation in financial derivatives (as opposed to commodity-linked derivatives) was generally associated with the break-down in 1971 of the Bretton-Woods system of fixed exchange rates. Volatile exchange rates ushered the world financial system in a new era of deregulation and financial innovation with the introduction of currency futures, options, swaps, swaptions, etc... as illustrated in Figure 1. As early as 1972, currency futures started to trade at the newly established International Monetary Market (a subsidiary of the Chicago Mercantile Exchange). Soon the deregulation of interest rates in the United

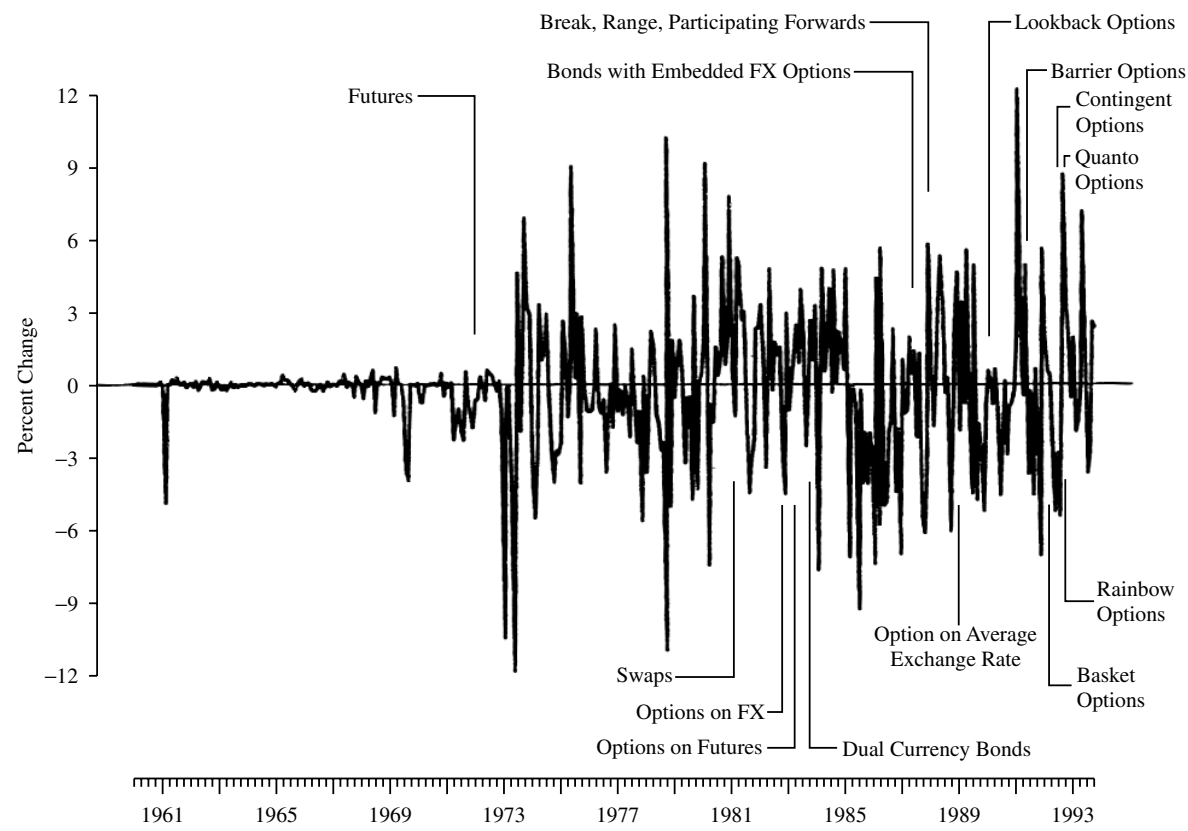

Figure 1 Percent change in yen/USD exchange rate. Source: Smithson, C. W. and C. W. Smith, Jr., with D. Sykes Wilford. Managing Financial Risk (Irwin, 1995), p. 22. 
States set in motion the introduction of interest rate derivatives, which eventually would dwarf currency and commodity derivatives. In 1977, the Chicago Board of trade introduced what was soon to become the most successful contract of all times US Treasury bond futures. When the world became a riskier place firms and financial institutions naturally sought safe harbor by hedging with financial derivatives.

\section{DERIVATIVES AND THE WEALTH OF NATIONS}

Indeed derivatives are sophisticated instruments whose spiraling success over the years has largely been driven by increased price volatility in commodities, currencies, stock prices, and interest rates. They fundamentally facilitate efficient risk transfer from firms, which are ill-equipped to bear risk and which would rather not be exposed to risk to firms which have excess risk-bearing capacity and are willing to take on exposure to risk. The first group is known as hedgers, who participate in derivatives trading for reducing or eliminating a pre-existing price risk: for example, airline companies are active participants in kerosene derivatives to limit their exposure to fluctuations in jet fuel prices. The second group is loosely known as speculators, who trade derivatives in the pursuit of profit and therefore willingly accept an increase in their exposure to risk: proprietary trading desks of investment banks or hedge funds are archetypical speculators. Thanks to derivatives risk transfer has become far more precise and efficient as its cost plunged because of breakthrough in computer technology and financial theory.

Thus derivatives allow for economic agents - households, financial institutions, and nonfinancial firms - to avail themselves of the benefits of division of labor and comparative advantage at risk-bearing: but are derivatives indeed value creating and contributing to the wealth of nations? Shouldn't the major derivatives-linked disasters (the subject of this book) which are striking with predictable frequency some of the best managed firms in the world be construed as evidence of wealth destruction rather than wealth creation? After all, the cumulative losses of recorded derivatives, debacles are well in excess of $\$ 25$ billion and if one includes AIG the total is approaching \$200 billion. The answer is neither: derivatives are zero-sum games and what one side of a derivative contract loses the other side gains. Unlike physical destruction brought about by Mother Nature such as Hurricane Katrina or the Kobe earthquake, derivative debacles are at worst wealth transfer rather than wealth destruction. Unfortunately, for the shareholders of any of the derivative-stricken firms portrayed in this book who suffered dramatic and at times total losses on their investment, the impeccable economic rationalization that their wealth had been transferred (rather than lost) to lucky bankers, traders, or hedge funds holding the other side of the derivative contract 
brings them little solace! Shouldn't regulation be tightened to save managers from the abyss of derivative debacles?

As the allegoric cover of this book purports to illustrate the "tight rope walker" or "funambulist" (trader, treasurer, or risk manager ) can walk the straight path from one peak to the next (wealth creation) thereby avoiding the costly and time-consuming path down the mountain before climbing up again provided that he handles with aplomb the balancing pole (derivatives): otherwise he will lose his balance and fall in the abyss (death on landing or wealth destruction)!

\section{ORGANIZATION OF THE BOOK}

This book is not another treatise on financial derivative products. The purpose of this project instead is to unlock the secrets of derivatives by telling the stories of institutions, which played in the derivative market and lost big. For some of these unfortunate organizations, it was honest but flawed financial engineering which brought them havoc. For others it was unbridled speculation perpetrated by rogue traders, whose unchecked fraud brought their house down.

Each story is unique - reflecting in part the idiosyncratic circumstances of the firm's misuse of derivatives and allows the reader to familiarize himself with one derivative product at a time. Each chapter addresses one major derivative debacle by first narrating the story before deconstructing the financial architecture behind the flawed scheme. Each chapter is self-contained to facilitate the reading and comprehension: as a result, a number of key concepts are revisited under various guises throughout the book. Each chapter concludes with the lessons learnt or the "moral of the story": unsurprisingly organizational learning is found lacking as mistakes made by one firm keep being repeated by others.

In the process, the reader will discover various institutions ranging from multinational corporations to universal banks, central banks, trading companies, hedge funds, and municipalities while becoming acquainted with the lead character of the saga. Rather than following a chronological order, the book is organized along the families of derivative products: forwards, futures, options, and swaps (see Table 1 for short summaries of each debacle). Fortunately, the reader will discover that the basic architecture of each product is the same whether it is "derived" from currencies, commodities, interest rate products, or stock market indices.

The book is written for a general college-educated audience and does not presuppose any training in finance: as the reader explores each debacle key technical concepts are introduced and illustrated in the form of boxes set apart from the text. Simple numerical and graphical illustrations are built into the story to facilitate the 
Table 1 Contents of the Book

\section{Chapter 1 Introduction: derivatives and the wealth of nations}

\section{Part I FORWARDS}

Chapter 2 Shell Showa (1993). Currency traders rolled over dollar forwards hoping to recover initial losses. Concealed losses eventually amount to $\$ 1.07$ billion.

Chapter 3 Citibank (1964). Currency trader speculates that the pound sterling will not devalue. Speculative scheme is aborted early at a loss of $\$ 8$ million.

Chapter 4 Bank Negara (1994). Speculates in the foreign exchange market through forwards and incurs losses of $\$ 3.16$ billion.

\section{Part II FUTURES}

Chapter 5 Amaranth (2006). A hedge fund corners the natural gas futures market. After initial billions of speculative profits, Amaranth finally collapses for failing to meet margin calls losing $\$ 5$ billion for its investors.

Chapter 6 Metallgesellschaft (1993). Sells long-dated oil forwards hedged by "stacking and rolling" oil futures. Unable to meet margin calls, Metallgesellschaft has to be rescued by a consortium of banks after losing $\$ 1.6$ billion.

Chapter 7 Sumitomo (1995). Its chief copper trader corners the copper market first realizing large profits until regulators forced the firm to resume normal trading: $\$ 2.6$ billion lost.

\section{Part III OPTIONS}

Chapter 8 Allied Lyons (1991). Its treasury speculates on lower volatility of the dollar-pound exchange rate during the Gulf war by selling currency options.

Chapter 9 Allied Irish Bank (2002). Currency trader conceals a streak of speculative losses on yen forwards by writing deep-in-the-money currency options. Losses totaled \$694 millions.

Chapter 10 Barings (1995). Nick Leeson conceals a streak of speculative losses on Nikkei 225 futures leading to losses of $\$ 1.4$ billion and the collapse of the venerable House of Barings.

Chapter 11 Société Générale (2008). Jerome Kerviel undertakes wild proprietary trading on stock index futures first generating $\$ 1.5$ billion of gains before losing $\$ 7.4$ billion for SoGen.

\section{Part IV SWAPS}

Chapter 12 Procter \& Gamble (1994). Purchases leveraged interest swaps hoping to lower its cost of capital failing to understand that it effectively sold interest rate put options for financing the reduction of its cost of capital.

Chapter 13 Gibson Greeting Cards (1995). Purchases leveraged interest swaps to reduce its cost of capital. Lost \$27 million partially recovered after suing Bankers Trust which sold the swaps. 
Table 1 (Continued)

Chapter 14 Orange County (1995). Municipal finance pool uses excessive leverage and interest rate derivatives to turbo-charge its earnings. Forced into bankruptcy after $\$ 1.5$ billion of losses.

Chapter 15 Long-Term Capital Management (1998). Exploits quasi-arbitrage convergence trades in US treasuries using extreme leverage until the Asian financial crisis turns illiquidity into insolvency.

Chapter 16 AIG (2008). Sells credit default swaps without proper reserving for actual defaults. Losses in excess of $\$ 150$ billion forced the US government to the largest bail-out ever to stave off systemic financial collapse.

Chapter 17 JP Morgan Chase (2012). Trader Bruno Iksil, nicknamed the London Whale, accumulated outsized credit default swap positions (CDS) resulting in losses of $\$ 6.2$ billion. Was JP Morgan simply building a "macro-hedge" for the bank loan portfolio or was it running a stealth hedge fund in contravention of the new Volcker rule?

Chapter 18 From Theory to Malpractice: Lessons Learnt

intuition behind each story and to smooth the reader's discovery journey into the uncharted territories of derivatives. Safe travel and happy discovery!

\section{Bibliography}

Briys, E. and F. de Varenne. The Fisherman and the Rhinoceros: How International Finance Shapes Everyday Life (John Wiley \& Sons Inc., 2000).

Chew, L. Managing Derivative Risks: The Use and Abuse of Leverage (John Wiley \& Sons, 1996).

Edwards, F. R. and C. W. Ma. Futures and Options (McGraw Hill, 1992).

Jacque, Laurent L. International Corporate Finance (John Wiley \& Son, 2014).

Jorion, P. Value at Risk: The New Benchmark for Managing Financial Risk (McGraw Hill, 3rd edn., 2007).

Marthinsen, J. Risk Takers: Uses and Abuses of Financial Derivatives (Pearson Addison-Wesley, 2005).

Miller, M. H. Merton Miller on Derivatives (John Wiley \& Sons, 1997).

Teweles, R. J. and F. J. Jones, edited by Ben Warwick. The Futures Game: Who Wins, Who Loses and Why (McGraw Hill, 1999 3rd edn). 